\title{
MEMBER STATES' LIABILITY FOR JUDICIAL ERROR RESULTING IN BREACHES OF EUROPEAN UNION LAW
}

\author{
Valentin Paul Neamt PhD \\ „Vasile Goldis” Western University of Arad \\ e-mail: valentinpaulnmt@gmail.com
}

(Received November 2015; Accepted January 2016)

\begin{abstract}
This paper presents the remedies available to persons whose European law rights have been infringed by judgments given by national Courts. The paper firsts presents the concept of state liability for judicial errors in relation to European law, as it stems from the case-law of the Court of Justice of the European Union, then goes on to show how the European Court of Human Rights may give redress to such aggrieved parties. Finally, it discusses the differences in the possibility of redress given by the two courts and the compatibility between their approaches, finally leading to a discussion on the possible convergence of the two.

Keywords: liability, judicial errors, European Law.
\end{abstract}

The present paper presents the remedies available to a legal person who has been adversely affected by a national court's interpretation of European law, interpretation which is contrary to the interpretation given by the Court of Justice of the European Union (hereinafter referred to as "The CJEU"). The first part of the paper will present the legal framework regarding the preliminary reference procedure enshrined in the Treaty on the Functioning of the European Union (hereinafter referred to as "The TFEU". The second part will present the remedies made available by the CJEU to people who have been adversely affected by national courts judgments in relation to European law. The third part will offer a glimpse of the remedies given by the European Court of Human Rights to people adversely affected by a national court's judgment in relation to European law. The fourth part will contain the author's conclusions and a comparative analysis of the afore-mentioned remedies.

\section{Legal framework}

The European Union has a task that is, in many ways, unrivaled in other preceding legal systems. With a number of 27 Member States, each having different judicial systems, it must ensure that individual people's rights are upheld and that European citizens' rights enjoy an effective protection in each of the 27 Member States. One of the main tools at the European Union's disposal is the preliminary reference procedure. Put simply, when a national court has some doubts regarding the interpretation of European legislation it has the possibility of referring a question to 
Member States' liability for judicial error resulting in breaches of European Union Law

the Court of Justice of the European Union in order to obtain the clarification it requires. When that court is a court against whose decisions there is no judicial remedy under national law, that court is compelled to bring the case before the CJEU.

The relevant treaty provisions are as follows:

Art. 267 TFEU (ex. article 234 TEC)

The Court of Justice of the European Union shall have jurisdiction to give preliminary rulings concerning:

(a) the interpretation of the Treaties;

(b) the validity and interpretation of acts of the institutions, bodies, offices or agencies of the Union;

Where such a question is raised before any court or tribunal of a Member State, that court or tribunal may, if it considers that a decision on the question is necessary to enable it to give judgment, request the Court to give a ruling thereon.

Where any such question is raised in a case pending before a court or tribunal of a Member State against whose decisions there is no judicial remedy under national law, that court or tribunal shall bring the matter before the Court.

(...)

Of course, the most important issue regards a court against whose decision there is no remedy. Essentially, if before a case is finally decided, at least one of the courts makes a preliminary reference to the CJEU, the risk of any person's rights deriving from EU law being infringe is practically zero.

However, the reverse of such a mechanism is that it completely overloads the CJEU's docket, seeing as courts from a number of Member States will constantly bombard you with questions as soon as an issue of interpretation regarding European law is raised before them. To keep the system from being unwieldy, and to and to keep otherwise irrelevant questions from being referred, the CJEU took it upon itself to limit the courts' obligation to refer. The first limitation of national courts' duties came to be in Da Costa [1], where the CJEU ruled that courts are not bound to their duty to make a request for a preliminary ruling when "the question raised is materially identical with a question which has already been the subject of a preliminary ruling in a similar case."

The second limitation came about in the Cilfit [2] case. Without going into details regarding the decision, the Italian Court of Cassation had a case before it where one of the parties requested the national court to make a request for a preliminary ruling regarding some legal aspects that the court itself considered as being obvious. The Court of Cassation did make a reference to the CJEU, asking, in essence, if a national court is bound to make a request for a preliminary ruling when one of the parties requests an interpretation of European law, when the interpretation seems to be obvious. The CJEU took the opportunity to lay down 
three alternative conditions when a national court against whose decision there is no judicial remedy may refrain from referring a question to the court of justice:

1) if the question is irrelevant to its judgment;

2 ) is the Court has already interpreted the point of law in the context of other proceedings;

3 ) if the correct interpretation of European law is so obvious as to leave no room for interpretation.

This, of course, gave significant freedom to national courts when deciding if a reference for a preliminary ruling is necessary, while also opening the door for possible judicial errors stemming from an incorrect interpretation of European law.

\section{Liability for judicial errors under European law}

The consequence of the leeway given to national courts became apparent in Kobler [3]. The case concerned a ruling made by the Austrian Supreme Court which was in breach of European law. Without going into the substantive law implied, to sum up: a German national was deprived of his rights under European law because the Austrian courts, including the Austrian Supreme Court failed to refer a question to the CJEU in the concerned matter, relying on an interpretation given by the court in a similar matter. In the CJEU's judgment it soon became apparent that the interpretation given by the Austrian Supreme Court was not in line with the Court's own interpretation of the relevant provisions of European law.

The CJEU found that a Member State is liable for damages caused to private persons as a consequence of judgments handed down by national courts, including a member state's Supreme Court.

In doing so it relied on the doctrine of state liability for the breach of citizen's European law rights, developed in cases such as Frankovich [4] and Brasserie du Pecheur and Factortame [5]. The conclusion was that liability can also be applied in relation to judicial errors.

The court held that "the principle that Member States are obliged to make good damage caused to individuals by infringements of Community law for which they are responsible is also applicable where the alleged infringement stems from a decision of a court adjudicating at last instance where the rule of Community law infringed:

- is intended to confer rights on individuals;

- the breach is sufficiently serious;

- there is a direct causal link between that breach and the loss or damage sustained by the injured parties. In order to determine whether the infringement is sufficiently serious when the infringement at issue stems from such a decision, the competent national court, taking into account the specific nature of the judicial function, must determine whether that infringement is manifest. It is for the legal 
Member States' liability for judicial error resulting in breaches of European Union Law

system of each Member State to designate the court competent to determine disputes relating to that reparation. [6]"

Regarding the liability of the Austrian Supreme Court in particular, the Court found that the conditions numbered 1 and 3 were fulfilled in this care. While the CJEU ruled that the Austrian Supreme Court did not fulfill its obligations under article 267 TFEU, the conditions of Cilfit not being fulfilled, it did not commit a "manifest breach", and, as such, the Austrian State was not liable.

From Kobler alone, it would seem that a state will not be held liable for breaches of EU law simply for failing to fulfill its obligations under article 276 TFEU.

The provisions were further elaborated upon in Traghetti del Mediterraneo [7]. The questions were submitted before the judgment in Kobler took place. One of the questions referred was if a state was liable on the basis of non-contractual liability to individual citizens for errors by its own courts in the application of Community law or the failure to apply it correctly and in particular the failure by a court of last instance to discharge the obligation to make a reference to the Court of Justice.

While the Court reaffirmed the conditions laid out in Kobler, it emphasized that "considerations linked to the need to guarantee effective judicial protection to individuals of the rights conferred on them by Community law similarly preclude State liability not being incurred solely because an infringement of Community law attributable to a national court adjudicating at last instance arises from the interpretation of provisions of law made by that court.

On the one hand, interpretation of provisions of law forms part of the very essence of judicial activity since, whatever the sphere of activity considered, a court faced with divergent or conflicting arguments must normally interpret the relevant legal rules - of national and/or Community law - in order to resolve the dispute brought before it.

On the other hand, it is not inconceivable that a manifest infringement of Community law might be committed precisely in the exercise of such work of interpretation if, for example, the court gives a substantive or procedural rule of Community law a manifestly incorrect meaning, particularly in the light of the relevant case-law of the Court on the subject), or where it interprets national law in such a way that in practice it leads to an infringement of the applicable Community law. [8]"

The CJEU held that the case "is to be assessed, inter alia, in the light of a number of criteria, such as the degree of clarity and precision of the rule infringed, whether the infringement was intentional, whether the error of law was excusable or inexcusable, and the non-compliance by the court in question with its obligation to make a reference for a preliminary ruling under the third paragraph of Article [267] $\mathrm{EC}$; it is in any event presumed where the decision involved is made in manifest disregard of the case-law of the Court on the subject." 
Neamt V.P. (2016)

Member States' liability for judicial error resulting in breaches of European Union Law

A further clarification was also made: proving "manifest breach" does not equal intentional fault or serious misconduct on the part of the court. Regarding an Italian law limiting judicial liability to only such cases, the CJEU had the following to add:

"Accordingly, although it remains possible for national law to define the criteria relating to the nature or degree of the infringement which must be met before State liability can be incurred for an infringement of Community law attributable to a national court adjudicating at last instance, under no circumstances may such criteria impose requirements stricter than that of a manifest infringement of the applicable law [9]"

The conclusions from the above-mentioned judgments is that a failure to refer, in and of itself, is not liable to make a member state liable and that a number of other conditions need to be fulfilled for the Kobler judgment to be applicable.

This, of course, begs the question of in which circumstances a member State will, in fact be liable, for breaches of European law and how and when can it be decided that a court made a decision in "manifest disregard of the case-law of the Court on the subject". What we do know is that a "manifest b breach" doesn't have to mean serious misconduct or intentional fault.

While there have been recent cases in which a national court against whose decision there is no judicial remedy was found to be in breach of the obligation laid down by art. 267 TFEU, there have been no recent clues as per how to define a "manifest infringement". Even though there have been questions referred to the CJEU regarding courts of last instance that have failed to fulfill their duty of asking for the court's guidance, for example X and Dijk [10] and Ferreira da Silva [11], there have been no other mentions of a "manifest breach"

\section{Liability under the European Convention on Human Rights}

The European Court of Human Rights' (hereinafter referred to as "The ECHR") interest in the preliminary reference procedure first came about in the case of Ullens De Schooten and Rezabek V. Belgium [12].

In the context of national proceedings, the applicants sought a reference for a preliminary ruling in order to ascertain the compatibility of Belgian legislation with the European treaties. Their requests had been denied. The plaintiffs brought the matter before the ECHR, claiming that their fundamental rights had been infringed. The Court had to rule if the refusal constituted a breach of article 6 (1) of the European Convention on Human Rights (hereinafter referred to as "The Convention") which entails the right to a fair trial. It concluded that the right to a fair trial "takes on particular significance in the jurisdictional context of the European Union. The purpose of implementing the third paragraph of Article 234 of the Treaty establishing the European Community (now Article 267 of the Treaty on the Functioning of the European Union) is, as the Court of Justice has pointed 
Member States' liability for judicial error resulting in breaches of European Union Law

out, to ensure "the proper application and uniform interpretation of Community law in all the Member States", and more particularly "to prevent the occurrence within the Community of divergences in judicial decisions on questions of Community law.

It should further be observed that the Court does not rule out the possibility that, where a preliminary reference mechanism exists, refusal by a domestic court to grant a request for such a referral may, in certain circumstances, infringe the fairness of proceedings - even if that court is not ruling in the last instance, whether the preliminary ruling would be given by a domestic court or a Community court. The same is true where the refusal proves arbitrary that is to say where there has been a refusal even though the applicable rules allow no exception to the principle of preliminary reference or no alternative thereto, where the refusal is based on reasons other than those provided for by the rules, and where the refusal has not been duly reasoned in accordance with those rules. [13]"

In the case, the ECHR did conclude that the national court had indeed fulfilled its obligation. The ECHR stated that "With demonstrative reasoning, it found that there was no reasonable doubt as to the inapplicability of Article 86 of the Treaty to the laboratories referred to in Article 3 of Royal Decree no. 143, and that an answer by the Court of Justice as to the interpretation of the other abovementioned provisions of the Treaty "could not affect the outcome of the present dispute" [14]".

An interesting turn of events came about before the European Court of Human Rights in the case of Dhahbi v Italy [15]. The applicant, a Tunisian national at the time of the proceedings, had filed a request for a form of social benefit he considered he was entitled to, based on the association agreement between the European Union and Tunisia - known as the Euro-Mediterranean Agreement which had been ratified by Italy.

His claim was dismissed in first instance and at an appellate court. He made an appeal on points of law to the Court of Cassation. Both before the appellate Court, as well as the Court of Cassation he asked for request for a preliminary ruling to be sent to the CJEU regarding the legal interpretation of the agreement's applicability to the case. In both cases his requests were refused.

In this context, the ECHR clearly laid out the principles derived from the Ullens De Schooten and Rezabek V. Belgium and another similar judgment in Vergauwen and Others v. Belgium [16]. It stated that:

"- Article $6 \$ 1$ requires the domestic courts to give reasons, in the light of the applicable law, for any decision refusing to refer a question for a preliminary ruling;

- when the Court hears a complaint alleging a violation of Article $6 \S 1$ on this basis, its task consists in ensuring that the impugned refusal has been duly accompanied by such reasoning; 
- whilst this verification has to be made thoroughly, it is not for the Court to examine any errors that might have been committed by the domestic courts in interpreting or applying the relevant law;

- in the specific context of the third paragraph of Article 234 of the Treaty establishing the European Community (current Article 267 of the Treaty on the Functioning of the European Union (TFEU)), this means that national courts against whose decisions there is no judicial remedy under national law, and which refuse to request a preliminary ruling from the CJEU on a question raised before them concerning the interpretation of European Union law, are required to give reasons for such refusal in the light of the exceptions provided for by the case-law of the CJEU. They must therefore indicate the reasons why they have found that the question is irrelevant, that the European Union law provision in question has already been interpreted by the CJEU, or that the correct application of EU law is so obvious as to leave no scope for any reasonable doubt." [17]

The ECHR found that the Court of Cassation's judgment contained no reference to the applicant's request for a preliminary ruling or to the reasons for which the request was denied. It then concluded that the court did not fulfill its obligations under article 6.1 of the Convention.

A similar case came before the ECHR in Schipani and Others v. Italy [18]. Several Italian doctors had brought an action for damages against the Italian State for its failure to implement Directive 82/76. Case no. C-131/97 was referred to the CJEU, the Court deciding that Italy hadn't properly implemented the directive and that, in principle, citizens affected by the Italian State's failure were entitled to damages. In the context of the main proceedings, the lower Courts had dismissed the action, the case coming before the Court of Cassation. The parties had requested that a reference for a preliminary ruling be made to the CJEU, but the Court did not proceed in accordance with their request.

In its judgment, the ECHR started by reaffirming the provisions of Vergauwen and Dhabhi, quoted above. After analyzing the contested decision, the ECHR found that there was no direct reference to the plaintiff's request of having the matter referred to the CJEU. It was true, however, that the Court, in the body of the contested decision did make a reference to the right of reparation in similar cases, as derived from the case law of the CJEU. However, the Court did not find this mention as being satisfactory, in spite of the Italian government's arguments, concluding that there has been a breach of article 6,1 of the Convention. It stated that from the concise mention it could not be established if the Court of Cassation had considered that the conditions of Cilfit had been applied or that the court simply ignored the matter and, as such, it should be considered a breach of its legal obligation.

The decision was not unanimous. Judge WOJTYCZEK had a diverging opinion. His opinion was that the obligation of giving suffices motivation for any judicial 
decision is proportional to the rights that threaten to be infringed by mean of the contested decision. The judge spoke about the utmost importance of motivating decisions in the sphere of criminal law, due in particular to the grave consequences that any breach of rights in criminal law proceedings might have on any natural or legal person that is brought before a court. He concluded that the ECHR case law in the matter of an obligation of a court against whose decision there is no judicial remedy to refer question to the Court of Justice might be disproportionately harsh, the mere fact of not referring not being able to prove that the parties were not given their right to a fair trial. He contrasted this with the court' case law regarding an obligation to refer a question to a national Constitutional Court in cases where one of the parties makes a claim of unconstitutionality regarding provisions of national law. By the Court's case law, the case of Pronina v Ukraine [19] being quoted, the duty of giving reasons isn't as stringent as the duty incumbent upon courts of last instance in the context of proceedings which raise question regarding the applicability of European law. As such, he found the duty to be excessive.

\section{Conclusions}

From the presented judgments we can see that the two European Courts have taken very different approached regarding the conditions in which Member States may be liable under European law for judicial errors in regard to the rights given to citizens under European law.

The approach taken by the CJEU is less strict than the one taken by the ECHR. Firstly, there is no liability of the Member State simply for the failure to make a reference for preliminary ruling upon the request of the parties, when not giving a reason for such refusal. More so, there is no penalty for failing to make a request for a preliminary ruling when, from the circumstances of the case it was obvious that the interpretation of European law did not permit the application of the Cilfit doctrine. More so, even if the Court's assessment is wrong and a person has their rights infringed, the state is not automatically liable, as was the case in the Kobler judgment, if the court did not make a "manifest breach".

The most striking thing about the judgments is that, in certain conditions, European citizens may have their rights infringed by a court and have no effective legal remedy. As in the case of Kobler, if the breach was not manifest, the legal person loses their rights under European law, without the state being liable. As the judgments are final there is normally no way of appealing the decision, with the exception of Member States which permit final decisions to be challenged based on subsequent rulings of the CJEU. Take for example article 21 (2) f law no. 554/2004 of Romania which permits otherwise final decisions in administrative matters to be challenged before Romanian Courts based on subsequent CJEU rulings that run counter to what was decided in the challenged decision. 
Neamt V.P. (2016)

Member States' liability for judicial error resulting in breaches of European Union Law

Regarding the ECHR case law, there are still many questions regarding the degree of justification a national court against whose decision there is no judicial remedy under national law must give in order for the obligation under article 6.1 of the Convention to be fulfilled. As we have seen from the presented cases, the fact that a court gives no justification or only hints at one will not be acceptable and will render the member state liable for breaches of the Convention.

However, the requirements of justification are so far very unclear. One could assume either that any semblance of justification, as long as it is not manifestly wrong would be accepted by the Court, even though it does not fully comply with the judgment in Cilfit. One cannot be certain of the degree of scrutiny such a decision would be put under until there are more cases decided on this basis.

One important difference needs to be made between the classifications of rights for the infringement of which the courts consider that reparation is due. The CJEU considers that reparation is due exactly for the infringement of the substantive rights conferred by the treaties, even though it does condition this to the "manifest breach" doctrine. As we have seen, infringements of their implicit rights to have their question referred to the CJEU do not constitute a right for reparation. On the other hand, the ECHR only concerns itself with breach of the parties' rights of having a question sent for a preliminary ruling. The ECHR has clearly stated that it is not concerned with the per se rights infringed by the judgment if the right to a fair trial was observed. This also means that, potentially, plaintiff could obtain damages for breach or article 6.1. of the Convention even though their substantive rights under European law were not infringed - for example, if a court dismissed their request for a preliminary ruling without giving a reason when the question raised before the court is completely obvious. This could, in theory, give rise to people making absurd claims before courts against whose decision there is no judicial remedy under national law hoping that the court makes an error in giving reasons in order for them to obtain reparation.

The divergence between the CJEU and the ECHR is profoundly different in the possible outcomes somebody might obtain if he or she were to bring damages. In certain conditions, this creates the possibility of "shopping" for a favorable court, based on the concrete circumstances of the case. This could be made no only in relation to the substantive European law concerned, but also to the applicable national legislation and maybe even applicable national case law since in Traghetti del Mediterraneo the CJEU held that the Member States are free to lay down the criteria to the nature or degree of the infringement which attracts the liability of member states.

Aside from the European Convention on human rights, the European Union has its own legal text regarding fundamental rights. It was drafted by the European Convention and solemnly proclaimed on 7 December 2000 by the European Parliament, the Council of Ministers and the European Commission. After the 
Member States' liability for judicial error resulting in breaches of European Union Law

ratification of the Treaty of Lisbon in 2007, the Charter of Fundamental Rights of the European Union (hereinafter referred to as "The Charter") has the same legal value as the European Union treaties.

It also holds the right to a fair trial as being a fundamental right. Article 47 states that:

"Everyone whose rights and freedoms guaranteed by the law of the Union are violated has the right to an effective remedy before a tribunal in compliance with the conditions laid down in this Article.

Everyone is entitled to a fair and public hearing within a reasonable time by an independent and impartial tribunal previously established by law. Everyone shall have the possibility of being advised, defended and represented.

Legal aid shall be made available to those who lack sufficient resources in so far as such aid is necessary to ensure effective access to justice."

Article 6.1 of the Convention reads as follows:

"In the determination of his civil rights and obligations or of any criminal charge against him, everyone is entitled to a fair and public hearing within a reasonable time by an independent and impartial tribunal established by law. Judgment shall be pronounced publicly but the press and public may be excluded from all or part of the trial in the interests of morals, public order or national security in a democratic society, where the interests of juveniles or the protection of the private life of the parties so require, or to the extent strictly necessary in the opinion of the court in special circumstances where publicity would prejudice the interests of justice."

A parallel reading of the provisions does not give rise to any impression that either one of the legal texts would give more or less protection to plaintiffs in the context of actions to which article 367 applies. However, as far as I know so far, there have been no references made to the CJEU regarding a breach of the parties' fundamental rights because a court had refused to mare a reference to the CJEU. It must be borne in mind that the Charter is still a relatively new instrument in the Union, being adopted officially in 2007, long after the decision in Kobler. However, there has not been any mention of infringement of fundamental rights in subsequent judgments given by the CJEU in which it was decided that a court against whose decision there is no judicial remedy under national law did not fulfill its obligation under art. 267 (3) TFEU.

There is of course the matter that the ECHR and CJEU have a different interpretation of the right to a fair trial. It must be borne in mind that although, through the Treaty of Lisbon the groundwork for the European Union joining the Convention was laid down, the Convention being modified through Protocol no. 14 , which entered into force in 2010 , so as to permit a supra-national organization such as the European Union to be part of it, there has been no consensus on the accession. On 18 December 2014, the CJEU delivered a negative opinion on the 

particular characteristics of the EU" [20], it stated that EU's accession to the ECHR under the provisions of the current draft agreement would undermine the autonomy and primacy of EU law.

If the EU does ever accede to the Convention, there will be a question referring a potential breach of article 6.1, but until then it seems that the CJEU does not see a failure to refer as a breach of fundamental rights deserving reparation in itself.

Regarding the apparent "weakness" of direct EU remedies for judicial errors leading to an infringement of rights conferred under European law, the delicate political situation must also be observed, as Member States may object to the EU introducing European wide legal procedures. As one author noted "[s]ome applaud the Court for treading a difficult pate between the need to respect national legal autonomy, and the competing need to promote the effective enforcement of EU law [21]". As such, the court is inclined to let Member States set their own procedures and limits to judicial liability, as long as the minimum levels of Kobler are observed. Another author had this to say about the interplay: "this field sits atop two tectonic plates. On the one hand, there is the logic of competing legal orders. This pushes for the primacy of EU law but acknowledges the autonomy of local legal orders, the sensitivities involved, and the difficulty of imposing uniform and centralized solutions [22]".

From the above-mentioned judgments, there is still a degree of uncertainty regarding the conditions under a person may obtain reparation for the infringements of their right under European law. While the CJEU case law has been around for some time, further clarification has been lacking. Regarding the ECHR's case law, it must be remembered that the judgments are still very recent Dhabhi was decided in 2014, while Schipani was decided in 2015. Until the courts give further guidance on the subject, we must conclude that people whose rights are affected by a judicial error will still face a fair amount of uncertainty when seeking remedies.

\section{Notes}

[1] Joined Cases 28 to 30/62 - Da Costa v Nederlandse Belastingadministratie (1963) ECR 31

[2] Case C-283/81 - Srl CILFIT and Lanificio di Gavardo SpA v Ministry of Health. (1982)

[3] Case C-224/01 - Gerhard Kobler v Republic of Austria (2003), ECR I-10239.

[4] Joined Cases C-6/90 and C-9/90 Andrea Francovich and Danila Bonifaci and others v Italian Republic (1991), ECR I-05357.

[5] Brasserie du Pecheur and Factortame (1996) ECR I-1029 and Case C-54/96 Dorsch Consult (1997) ECR I-4961.

[6] Kobler, cited above, para. 59

[7] C-173/03 - Traghetti del Mediterraneo SpA v Repubblica Italiana (2006), ECR I-05177 
Neamt V.P. (2016)

Member States' liability for judicial error resulting in breaches of European Union Law

[8] Ibid, paras. $33-43$.

[9] Ibid, para. 44.

[10] Joined Cases C-72/14 and C-197/14 - X v Inspecteur van Rijksbelastingdienst and

T.A. Van Dijk v Staatssecretaris van Financien, not yet reported.

[11] Case C-160/14 - João Filipe Ferreira da Silva e Brito and Others v Estado portugues, not yet reported.

[12] Case of Ullens De Schooten And Rezabek V. Belgium (Applications nos. 3989/07 and 38353/07)

[13] Ibid., paras. 58-59.

[14] Ibid., para. 65.

[15] Case of Dhahbi V. Italy (Application no. 17120/09)

[16] Vergauwen v. Belgium (Application no. 4832/04)

[17] Dhabhi v Italy, cited above, para. 31

[18] Schipani and Other v. Italy (application no. 38369/09)

[19] Case Of Pronina V. Ukraine (Application no. 63566/00)

[20] OPINION 2/13 OF THE COURT (Full Court) of 18 December 2014

[21] Paul Craig, Grainne de Burca - EU Law: Text, Cases, and Materials, 5th Edition, Oxford University Press, Oxford, 2011, page 254.

[22] Damian Chalmers, Gareth Davies, Giorgio Monti - European Union Law: Cases and Materials 2nd Edition, Oxford University Press, Oxford, 2010, page 312.

\section{Bibliography}

1. Damian Chalmers, Gareth Davies, Giorgio Monti - European Union Law: Cases and Materials 2nd Edition, Oxford University Press, Oxford, 2010;

2. Paul Craig, Grainne de Burca - EU Law: Text, Cases, and Materials, 5th Edition, Oxford University Press, Oxford, 2011;

\section{Judgments of the Court of Justice of the European Union:}

3. Joined Cases 28 to 30/62 - Da Costa v Nederlandse Belastingadministratie (1963) ECR 31

4. Case C-283/81 - Srl CILFIT and Lanificio di Gavardo SpA v Ministry of Health. (1982)

5. Case C-224/01 - Gerhard Kobler v Republic of Austria (2003), ECR I-10239.

6. Joined Cases C-6/90 and C-9/90 Andrea Francovich and Danila Bonifaci and others v Italian Republic (1991), ECR I-05357.

7. Case C-46/93 - Brasserie du Pecheur and Factortame (1996) ECR I-1029;

8. Case C-173/03 - Traghetti del Mediterraneo SpA v Repubblica Italiana (2006), ECR I-05177.

9. Joined Cases C-72/14 and C-197/14 - X v Inspecteur van Rijksbelastingdienst and T.A. Van Dijk v Staatssecretaris van Financien, not yet reported.

10. Case C-160/14 - João Filipe Ferreira da Silva e Brito and Others v Estado portugues, not yet reported. 
"Vasile Goldiș" Western University of Arad

Neamt V.P. (2016)

Member States' liability for judicial error resulting in breaches of European Union Law

\section{Judgments of the European Court of Human Right:}

11. Case Of Ullens De Schooten And Rezabek V. Belgium (Applications nos. 3989/07 and 38353/07)

12. Case Of Dhahbi V. Italy (Application no. 17120/09)

13. Vergauwen v. Belgium (Application no. 4832/04)

14. Dhabhi v Italy, cited above, para. 31

15. Schipani and Other v. Italy (application no. 38369/09)

16. Case Of Pronina V. Ukraine (Application no. 63566/00) 